\title{
FAKTOR -FAKTOR SOSIAL EKONOMI DAN PSIKOLOGIS YANG BERHUBUNGAN DENGAN TINGKAT PARTISIPASI ANGGOTA KOPERASI CITRA BARU SEKTOR AGRIBISNIS
}

\author{
Redy Badrudin ${ }^{1}$ \\ Nusril $^{1}$ \\ Aminah $^{2}$ \\ ${ }^{1}$ Staf Pengajar Jurusan Sosial Ekonomi Pertanian Fak. Pertanian UNIB \\ ${ }^{2}$ Alumni Jurusan Sosial Ekonomi Pertanian Fak. Pertanian UNIB
}

\begin{abstract}
The purpose of this research were to know description socio economic and pshicology factors, Participation rate and the related socio economic and pshicology factors and participated members Citra Baru Cooperative in agribusiness sector. This Researh use description and analysis methode use Statistic non parametric Rank Spearman correlation, and interval in 95 $\%$ significant. The factors is age, formal education, experience, family members, revenue of house hold, motivation credit and perception to the service, $n$ agribusiness prorame. The research show in Dec $13^{\text {th }}-$ Jan $13^{\text {th }}$ in riak siabun village sukaraja Seluma. Participation rate in middle category, the Factors that related are formal education experience, motivation, and perception to the service
\end{abstract}

Keywords : Socio economis and pshicolgy factors, cooperative, participation.

\section{PENDAHULUAN}

Peranan sektor pertanian sebagai leading sektor dalam struktur perekonomian propinsi Bengkulu masih sulit digeser oleh sektor-sektor lainnya. Kondisi itu terlihat dari relatif besarnya kontribusi sektor pertanian dalam PDRB Propinsi Bengkulu. Sektor pertanian menyumbang pada PDRB Propinsi Bengkulu sebesar 40,07 persen, inilah yang menjadi alasan utama yang menyebabkan bahwa sektor pertanian harus terus ditingkatkan (Anonim, 2004)

Menurut Soekartawi (2000), pemberdayaan ekonomi rakyat dapat diwujudkan dengan menerapkan strategi pengembangan yang berwawasan agribisnis. Pengembangan agribisnis merupakan salah satu upaya untuk mendorong dan menarik munculnya industri baru disektor pertanian, menciptakan struktur perekonomian yang tangguh, efisien, dan fleksibel, 
menciptakan nilai tambah, meningkatkan penerimaan devisa, menciptakan lapangan pekerjaan, dan memperbaiki pembagian pendapatan.

Koperasi merupakan salah satu wadah dan wahana yang sesuai bagi pelaksanaan dibidang perekonomian, terutama dalam usaha peningkatan kemampuan yang lebih besar bagi golongan ekonomi lemah untuk berperan serta dalam pembangunan. Pembangunan koperasi sebagai bagian integral pambangunan ekonomi perlu dilanjutkan dan diarahkan untuk mewujudkan bahwa koperasi merupakan badan usaha dan sekaligus sebagai penggerak ekonomi rakyat, disemua kegiatan perekonomian, sehingga mampu berperan utama dalam peningkatan kondisi ekonomi dan kesejahteraan masyarakat (Subyakto,1995)

Pada hakekatnya koperasi tidak bertujuan untuk mencari keuntungan (profit), akan tetapi lebih mengutamakan kesejahteraan anggota, sebagai contohnya yaitu dengan mengembalikan hasil usaha yang didapatkan oleh koperasi kepada anggotanya sesuai dengan besar kecilnya jasa anggota dalam usaha koperasi tersebut, untuk itu koperasi perlu terus dibina dan dikembangkan agar tumbuh sehat dan kuat sehingga koperasi semakin berakar dan perannya makin besar dalam kehidupan sosial ekonomi masyarakat. Untuk mencapai maksud tersebut, pemerintah telah melakukan upaya-upaya diantaranya: pemberian tambahan modal kegiatan usaha, pembinaan manajemen,mengikutsertakan koperasi dalam mengelola berbagai bantuan pemerintah. Melalui upaya-upaya tersebut, koperasi diharapkan akan semakin berkembang, mandiri, permodalannya kuat, dan mampu bersaing dengan lembaga-lembaga ekonomi lainnya.

Menurut data Kementerian Negara Koperasi dan UKM, jumlah simpanan yang dihimpun koperasi kredit hingga 2002 mencapai Rp1,5 triliun. Sekitar 10 juta nasabah telah 
menikmati pinjaman dari koperasi kredit yang tersebar di seluruh pelosok tanah air, salah satunya adalah Koperasi Simpan Pinjam Citra Baru sektor agribisnis untuk wilayah propinsi Bengkulu. Koperasi Simpan Pinjam Citra Baru berbadan hukum No: 02/BH/DK/PPKM/KEP/II/2001 yang bergerak dibidang simpan pinjam, merupakan salah satu koperasi percontohan di Propinsi Bengkulu yang lulus verifikasi dan juga dipercaya untuk mengelola dana perkuatan Koperasi simpan pinjam sektor Agribisnis sebesar Rp 1000.000.000,- (satu milyar rupiah)

Desa Riak Siabun mempunyai luas lahan pertanian + $3000 \mathrm{Ha}$, jumlah petani sebanyak 600 orang, sedangkan jumlah anggota koperasi sebanyak 145 orang. Tidak semua anggota koperasi mendapatkan pinjaman dana dari pihak koperasi, anggota yang mendapatkan dana pinjaman adalah anggota yang telah memenuhi persyaratan atau verifikasi dari pihak Koperasi Citra Baru Sektor Agribisnis. Adapun yang telah diberi pinjaman adalah petani, pekebun, dan juga pemasaran sarana produksi pertanian seperti sawit, karet, jagung, palawija, dan peternak ayam potong. Pinjaman kredit tersebut diberikan dengan tujuan membantu petani yang selama ini sangat terkendala pada masalah modal terutama dalam pengadaan saprodi.

Untuk menjamin apakah pinjaman benar-benar dimamfaatkan oleh petani. perlu adanya pengawasan dari pihak koperasi selaku pihak yang bertanggung jawab dalam penyaluran dana dengan cara terjun langsung kelapangan. Dalam pemberian dan penyaluran dana tentu ada persepsi yang berbeda dari masing-masing anggota, sebagian ada yang sangat merasakan kehadiran koperasi, dan ada juga yang merasa terbebani setelah mereka bergabung dengan koperasi, antara lain dari segi persyaratan, mereka harus memiliki modal sebesar Rp. 
500.000 untuk dapat menjadi anggota, dan mereka harus membayar uang simpanan pokok, wajib, dan bunga dari pinjaman mereka.

Jika dilihat dari perjanjian simpan pinjam dimanapun ada beban bunga, namun tidak semua anggota mengerti dengan hal tersebut, dan ini semua tergantung dari pendidikan dan pengalaman anggota tentang perkoperasian. Selain itu persepsi yang baik dari anggota juga timbul dari motivasi anggota untuk lebih meningkatkan kehidupan mereka terutama dibidang perekonomian, karena dengan anggapan bahwa dengan adanya bantuan pinjaman kredit untuk usaha mereka akan dapat terbantu terutama dalam masalah permodalan, dan koperasi memfasilitasinya yaitu antara lain dengan beban bunga lunak dan uang angsuran yang tidak memberatkan anggotanya, yang terpenting juga untuk kelancaran perjalanan program pinjaman kredit Agribisnis kedepan.

Pada dasarnya keberhasilan koperasi akan jauh lebih baik apabila diikuti oleh partisipasi aktif anggota koperasi khususnya dan masyarakat pada umumnya. Dalam hal ini tidak terlepas dari keterkaitan peran ganda anggota yaitu sebagai pemilik sekaligus sebagai nasabah, yang merupakan ujung tombak maju mundurnya koperasi. Partisipasi anggota diindikaskan dari kesediaan anggota untuk memikul dan menjalankan hak keanggotaan secara bertanggung jawab. Jika sebagian besar anggota koperasi sudah menunaikan kewajibannya dan melaksanakan haknya secara bertanggung jawab,terutama dalam hal pengembalian kredit, maka partisipasi anggota koperasi yang bersangkutan sudah dikatakan baik. Maka dari itu peneliti sangat tertarik melakukan penelitian yang berjudul "Faktor-Faktor Sosial Ekonomi dan Psikologis yang Berhubungan dengan Tingkat Partisipasi Anggota Koperasi Simpan Pinjam Citra Baru Sektor Agribisnis" 


\section{METODE PENELITIAN}

Metode pemilihan lokasi dilakukan secara sengaja (purposive) Penelitian dilakukan di Desa Riak Siabun Kecamatan Sukaraja Kabupaten Seluma Bengkulu Selatan. Dengan pertimbangan Bahwa Desa Riak Siabun sebagian besar petaninya merupakan anggota Koperasi simpan pinjam Citra Baru sektor agribisnis. Penelitian dilaksanakan pada tanggal 13 Desember 2006 sampai dengan 13 Januari 2007.

Dalam penelitian ini penentuan Responden adalah anggota Koperasi Simpan Pinjam (KSP) sektor Agribisnis di Desa Riak Siabun Kecamatan Sukaraja kabupaten Seluma Bengkulu Selatan. Dengan menggunakan metode Acak sederhana (simple random sampling) dimana setiap unit mempunyai peluang yang sama untuk dipilih sebagai responden. Dari 145 orang jumlah populasi, peneliti mengambil sampel sebesar 30\%, (Singarimbun, 1989) jumlah sampel yang diambil tidak boleh kurang dari $10 \%$ dari populasi, Jika jumlah sample yang diambil jumlahnya besar, teknik analisa yang digunakan untuk membandingkan antar kelompok seperti $t$ - test maka jumlah sample yang digunakan minimal 30 sampel, maka diperoleh sampel : 145 orang $\times 30 \%=43,5=44$ orang

Analisis data yang dilakukan dianalisis secara kualitatif dan kuantitaif. Data kualitatif berupa menggunakan analisa deskriptif dengan menggunakan tabulasi, dan urutan verbal, yang menghasilkan data atau informasi yang lengkap dan terperinci.

Data kuantitatif antara lain Dengan menggunakan metode analisis metode Statistik Non Parametrik.

Untuk menentukan kategori dari masing-masing tingkat variabel umur, pendidikan, pendidikan nonformal, Pengalaman, jumlah tanggungan keluarga, penerimaan rumah tangga, 
motivasi pengembalian kredit, persepsi terhadap pelayanan, persepsi terhadap program agribisnis.

Digunakan rentang nilai dengan rumus sebagai berikut :

Interval kelas $=\frac{\text { NilaiAtas }- \text { NilaiBawah }}{\sum \text { KategoriInterval }}$

Kemudian untuk menjawab tujuan dari penelitian ini, maka data-data yang diperoleh dilapangan dengan wawancara/kuisioner, dianalisis dengan menggunakan tabulasi dan analisis deskriptif. Sedangkan pengujian hipotesis digunakan korelasi rank spearman dilakukan dengan menggunakan formula sebagai berikut

Untuk menguji hipotesis dalam penelitian ini maka digunakan alat analisis statistik non parametrik, yaitu uji korelasi rank spearman (Siegel, 1986).

$$
r s=1-\frac{6 \sum_{i=1}^{N} d i^{2}}{N^{3}-N}
$$

Di mana :

rs $\quad=$ Koefisien Korelasi rank Spearman

$\mathrm{N} \quad=$ Jumlah Responden

di $=$ Selisih antara suatu variabel bebas dengan rangking variabel terikat pada responden ke-i

Jika terdapat adanya nilai observasi yang sama maka digunakan faktor koreksi, yaitu :

$$
\begin{aligned}
& T=\frac{t^{3}-t}{12} \\
& \sum X_{1}{ }^{2}=\frac{N^{3}-N}{12}-\sum T_{x i} \quad \sum Y_{1}^{2}=\frac{N^{3}-N}{12}-\sum T_{y}
\end{aligned}
$$

Sehingga rumus rs menjadi :

$$
r s=\frac{\sum X_{1}{ }^{2}+\sum Y^{2}-\sum d^{2}}{2 \sqrt{\sum X_{1}^{2} \sum Y^{2}}}
$$


Di mana :

$\sum \mathrm{T}=$ Banyak observasi sama pada suatu rangking

$\sum \mathrm{Xi}^{2}=$ Jumlah kuadrat variabel $\mathrm{X}$ ke-i yang dikoreksi

$\mathrm{i} \quad=(1,2,3,4,5,6,7,8,9)$

$\sum \mathrm{Y}^{2} \quad$ Jumlah kuadrat)

$\mathrm{Y}=$ Variabel terikat (Partisipasi anggota)

Untuk menguji tingkat signifikansinya, maka $t_{\text {hitung }}$ dibandingkan dengan $t_{\text {tabel }}$ dengan taraf kepercayaan $95 \%(\alpha / 2=0,025)$.

Adapun rumus untuk mencari nilai t-hitung adalah sebagai berikut Sugiyono (2003) :

$t_{\text {hitung }}=r s \sqrt{\frac{N-2}{1-r s^{2}}}$

Di mana :

rs $\quad=$ Koefisien korelasi rank Spearman

$\mathrm{N}=$ Jumlah Responden

Hipotesis secara matematisnya adalah sebagai berikut :

Ho: rs $=0$ : Variabel bebas berhubungan tidak nyata dengan variabel terikat

Hi : rs $\neq 0$ : Variabel bebas berhubungan nyata dengan variabel terikat

Adapun kriteria pengujiannya adalah sebagai berikut :

- Jika $-\mathrm{t}_{\text {hitung }}<-\mathrm{t}_{\text {tabel }}$ atau $\mathrm{t}_{\text {hitung }}>\mathrm{t}_{\text {tabel}}$, maka tolak Ho dan terima Hi, berarti ada hubungan yang nyata antara variabel bebas dengan variabel terikat.

- Jika $-\mathrm{t}_{\text {hitung }} \geq-\mathrm{t}_{\text {tabel }}$ atau $\mathrm{t}_{\text {hitung }} \leq \mathrm{t}_{\text {tabel}}$, maka terima Ho dan tolak Hi, berarti ada hubungan yang tidak nyata antara variabel bebas dengan variabel terikat.

Untuk melihat ada tidaknya hubungan antara karakteristik (X1 -X9) dengan tingkat partisipasi anggota Koperasi Citra Baru Sektor Agribisnis (Y), maka digunakan korelasi Rank Spearman (rs).

\section{HASIL DAN PEMBAHASAN}


melihat hubungan antara variabel bebas (faktor-faktor yang berhubungan dengan partisipasi ) dengan variabel terikat (partisipasi) apakah nyata atau tidak nyata.

Dari hasil perhitungan uji statistik maka dapat dilihat bahwa Pendidikan formal (X2) pangalaman (X4), Motivasi pengembalian kredit (X7 ), Persepsi terhadap Pelayanan (X8 ), mempunyai hubungan yang nyata dengan tingkat partisipasi (Y) anggota, sedangkan variabel umur (X1), Tanggungan keluarga (X5), Penerimaan RT (X6) Persepsi terhadap program agribisnis (X9) tidak memiliki hubungan yang nyata dengan tingkat partisipasi

\section{Umur}

Umur menunjukkan kedewasaan seseorang dalam menentukan sikap. Semakin tua seseorang maka tingkat kepatuhannya dalam menaati peraturan akan semakin tinggi. Berdasarkan Hasil Penelitian dapat diketahui nilai koefisien korelasi umur $\left(\mathrm{X}_{1}\right)$ dengan Partisipasi (Y). Hasil analisis uji t-hitung $(1,84274)$ lebih kecil dari nilai t-tabel 2,015367.

Dengan demikian hasil penelitian ini tidak mendukung hipotesis penelitian yakni umur memiliki hubungan yang nyata positif dengan tingkat partisipasi hal ini mengindikasikan bahwa berapapun umur anggota koperasi Citra Baru tidak berhubungan dengan tingkat partisipasinya sebagai anggota. Walaupun rata-rata umur anggota dikategorikan dalam usia produktif, dengan alasan lebih mampu berusaha semaksimal mungkin dalam mencapai keberhasilannya dalam bekerja dan mampu mengembalikan kredit pinjamannya kekoperasi.

Kaitannya dengan partisipasi terhadap koperasi adalah bahwa dengan usia yang masih produktif anggota koperasi lebih memiliki rasa tanggung jawab terhadap pekerjaan sesuatu 
pekerjaan, baik langsung ikut terlibat dalam koperasi, memberikan kontribusi, dan juga lebih patuh dalam menaati peraturan yang telah disepakati bersama-sama dengan anggota.

Penelitian ini didukung oleh Murtiningrum (2003) yang menyatakan bahwa umur tidak berhubungan nyata dengan tingkat partisipasi masyarakat penerima bantuan BRDP. Dikarenakan yang ikut berpartisipasi dalam proyek yaitu masyarakat dengan beberapa tingkat umur baik berumur muda maupun berumur tua.

Namun penelitian ini bertentangan dengan penelitian Sumadi (2003) yang menyatakan bahwa anggota KUD berhubungan dengan tingkat partisipasi, yang mana anggota yang berumur lebih tua menunjukkan bahwa mereka memiliki tingkat kepatuhan yang lebih tinggi dalam menaati peraturan, dan berkaitan dengan kemampuannya untuk berpartisipasi.

\section{Pendidikan Formal}

Pendidikan formal merupakan jenjang pendidikan yang ditempuh oleh anggota secara formal koperasi mulai dari SD sampai dengan perguruan tinggi.Berdasrakan uji statistik diperoleh bahwa nilai t-hitung $(2,30341)$ lebih besar dari t-tabel $(2,015367)$. Dengan demikian berarti hasil penelitian mendukung hipotesis penelitian di mana pendidikan formal memiliki hubungan yang nyata dengan partisipasi anggota

Berdasarkan hasil analisis statistik yang ternyata variabel pendidikan formal berhubungan nyata positif dengan partisipasi anggota.Dari hasil penelitian dapat dilihat bahwa rata-rata anggota berpendidikan setingkat SMP dan tidak ada anggota yang tidak menamatkan SD apalagi yang tidak bersekolah, ini dapat ditarik kesimpulan bahwa rata-rata berpendidikan cukup tinggi, dimana bahwa faktor pendidikan akan berhubungan dengan kemampuan anggota 
dalam menyerap informasi dari koperasi, tanpa pendidikan formal anggota akan kesulitan menyerap informasi yang diberikan koperasi.

Walaupun tingkat pendidikan anggota dari hasil penelitian umumnya rendah, namun tingkat pendidikan yang rendah tersebut kurang berpengaruh pada partisipasi anggota dan sebaliknya pendidikan yang tinggitidak menjamin anggota akan berpartisipasi yang lebih tinggi pula.

Hasil penelitian ini didukung oleh pendapat Danila (2004) di mana Pendidikan formal berhubungan dengan tinggi rendahnya partisipasi anggota KUD, dimana anggota yang berpendidikan tinggi lebih tinggi lebih mudah untuk berpartisipasi dan yang berpendidikan rendah merasa enggan untuk berpartisipasi. Tetapi Hasil penelitian ini bertentangan dengan hasil penelitian Yunanda (2006) di mana pendidikan tidak mempunyai hubungan yang nyata dengan tingkat partisipasi buruh panen dalam kegiatan dan program SISS di PT. Agricinal dikarenakan peranannya relatif kecil., dan rata-rata buruh panen memiliki pendidikan formal yang relative rendah.

\section{Lamanya Menjadi Anggota}

Lamanya jadi anggota menunjukan lamanya anggota bergabung dengan Koperasi Citra Baru Sektor Agribisnis. Diduga bahwa semakin lama anggota bergabung dengan koperasi maka akan semakin tinggi pula tingkat partisipasinya Berdasarkan Hasil Penelitian dapat diketahui nilai koefisien korelasi pengalaman $\left(\mathrm{X}_{4}\right)$ dengan Partisipasi (Y). Hasil analisis uji thitung (2.20021) lebih besar dari nilai t-tabel (2,015367) dengan taraf kepercayaan $95 \%$ $(\alpha / 2=0,025)$ 
Diketahui bahwa dengan lamanya jadi anggota mempunyai hubungan yang nyata positif dengan tingkat partisipasi Anggota. Ini menunjukan bahwa semakin lama anggota bergabung dengan koperasi mengakibatkan seseorang lebih kenal, akrab, dan tidak sungkan lagi untuk ikut serta dan membaur denganmasyarakat sekitar.(Tarto, dkk, 1997). Kaitannya dengan partisipasi anggota dalam koperasi, yaitu anggota yang sudah lama bergabung dengan koperasi maupun peraturan yang dibuat sudah lebih dipahami dan untuk ikut terlibat secara langsung dalam koperasipun sudah memiliki peluang yang besar.

\section{Jumlah Tanggungan Keluarga}

Jumlah tanggungan keluarga diduga berhubungan dengan tingkat partisipasi anggota , yaitu semakin banyak jumlah tanggungan semakin tinggi tingkat partisipasi anggota dalam berkoperasi.. Berdasarkan uji statistik diperoleh bahwa nilai t-hitung $(0,44175)$ lebih kecil dari t-tabel $(2,015367)$ yang berarti hasil penelitian tidak mendukung hipotesis penelitian di mana jumlah tanggungan memiliki hubungan yang nyata dengan partisipasi anggota.

Hasil penelitian mengidentifikasikan bahwa berapapun jumlah tanggungan keluarga anggota Koperasi Citra Baru Sektor Agribisnis tidak berhubungan dengan tingkat partisipasi anggota, karena keputusan untuk berpartisipasi yang berperan paling besar ditentukan oleh anggota itu sendiri yang merasakan kehadiran koperasi, jumlah anggota yang besar tidak mendorong peserta untuk berpartisipasi lebih aktif.

Penelitian ini tidak sesuai dengan penelitian Multiningrum (2003) tentang partisipasi masyarakat penerima bantuan BRDP pada usaha produktif pedesaan yang menjelaskan bahwa jumlah tanggungan keluarga berhubungan nyata dengan tingkat partisipasi masyarakat karena 
jumlah tanggungan yang banyak mendorong masyarakat dalam berpartisipasi, untuk berusaha untuk mencari tambahan penghasilan kerluarga untuk memenuhi kebutuhannya.

\section{Penerimaan Rumah Tangga}

Penerimaan rumah tangga diduga berhubungan nyata dengan tingkat partisipasi anggota Koperasi Citra Baru Sektor Agribisnis karena dengan pendapatan yang rendah mendorong anggota untuk berpartisipasi dengan koperasi karena dengan adanya koperasi anggota dapat terbantu untuk membeli saprodi guna menunjang kegiatan usahatani.

Berdasrakan uji statistik diperoleh bahwa nilai t-hitung $(0,77322)$ lebih kecil dari ttabel $(2,015367)$ yang berarti hasil penelitian tidak mendukung hipotesis penelitian di mana penerimaan memiliki hubungan yang nyata dengan partisipasi anggota

Hal ini diidentifikasikan bahwa penerimaan rumah tangga yang rendah tidak menjamin seseorang untuk ikut berpartisipasi dengan koperasi karena banyak dari mereka yang memanfaatkan sumber keuangan yang lain untuk berusahatani, seperti dari pinjaman teman bahkan lembaga keuangan lain.

Penerimaan yang diperoleh sangat berpengaruh terhadap partisipasi anggota koperasi Citra Baru sector agribisnis. Dapat terlihat bahwa anggota yang berpenghasilan rendah kurang partisipasinya dalam berkoperasi, karena tidak mempunyai waktu yang banyak dalam koperasi. Ia lebihmementingkan mencari penghasilan yang banyak guna memenuhi kebutuhan hidupnya dan juga keluarganya.

Penelitian ini didukung oleh Taufiq (2006) bahwa besar kecilnya penerimaan rumah tangga petani tidak mempengaruhi alokasi waktu kerja yang digunakan. 


\section{Motivasi Pengembalian Kredit}

Motivasi aggota dalam pengembalian kredit merupakan keinginan dari anggota untuk berpartisipasi dalam koperasi khususnya dalam pengembalian kredit. Motivasi diduga mempunyai hubungan yang nyata terhadap partisipasi yaitu semakin tinggi motivasi anggota dalam pengembalian kredit maka akan semakin tinggi pula tingkat partisipasi anggota koperasi, karena anggota sudah merasakan pentingnya koperasi dalam peningkatan usaha mereka.

Berdasarkan Hasil Penelitian dapat diketahui nilai koefisien korelasi motivasi pengembalian kredit $\left(\mathrm{X}_{7}\right)$ dengan Partisipasi (Y). Hasil analisis uji t-hitung $(2,44994)$ lebih besar dari nilai t-tabel $(2,015367)$ dengan taraf kepercayaan $95 \% \quad(\alpha / 2=0,025)$

Diketahui bahwa motivasi anggota dalam pengembalian kredit mempunyai hubungan yang nyata dengan tingkat partisipasi Anggota. Hasil penelitian menunjukkan bahwa motivasi anggota dalam pengembalian kredit tinggi halini mengidentifikasikan bahwa tingkat partisipasi anggota dengan koperasi juga tinggi, yang mana anggota merasa terbantu dengan kehadiran koperasi tersebut.

Tingkat motivasi anggota dalam pengembalian kredit adalah hal-hal yang melatar belakangi seseorang untuk berpartisipasi terhadap Koperasi Citra Baru Sektor Agribisnis. Berdasarkan hasil penelitian faktor pendorong untuk berpartisipasi sebagai anggota koperasi adalah karena membutuhkan biaya untuk berusahatani, dan koperasi agribisnis adalah salah satu wadah untuk menggerakkan perekonomian petani khususnya anggota. 
Penelitian ini didukung oleh Taufik (2006) yaitu semakin tinggi motivasi petani bekerja maka semakin banyak pula curahan waktu kerja yang dicurahkan untuk bekerja diperkebunan.

\section{Persepsi Anggota Terhadap Pelayanan}

Pelayanan merupakan perhatian khusus yang diterima oleh anggota dengan arti pelayanan yaitu pemberian layanan jasa yang dapat menarik anggota. Pelayanan diduga berhubungan secara positif dengan partisipasi anggota koperasi, karena dengan pelayanan yang baik dari pihak koperasi dapat mengakibatkan anggota untuk lebih berpartisipasi sebagai anggota.

Berdasarkan Hasil Penelitian dapat diketahui nilai koefisien korelasi pelayanan $\left(\mathrm{X}_{8}\right)$ dengan Partisipasi $(\mathrm{Y})$. Hasil analisis uji t-hitung $(2,42370)$ lebih besar dari nilai t-tabel $(2,015367)$ dengan taraf kepercayaan $95 \%(\alpha / 2=0,025)$. Diketahui bahwa pelayanan mempunyai hubungan yang nyata dengan tingkat partisipasi Anggota.

Hal ini diidentifikasikan bahwa pelayanan yang baik dari koperasi akan membuat anggota lebih terdorong untuk bergabung dengan koperasi dengan kata lain anggota akan lebih berpartisipasi dalam koperasi. Penelitian ini sesuai dengan teori Mutis (1992) yang mengemukakan bahwa tingkat partisipasi anggota berkaitan dengan pelayanan yang baik yang diberikan oleh pihak koperasi, dengan ditunjukkan pada penempatan anggota sebagai subyek dalam pengembangan koperasi, sehingga anggota merasa memiliki dan rasa bertanggung jawab pada koperasi.

\section{Persepsi Anggota Terhadap Program Agribisnis}


Persepsi merupakan penilaian anggota terhadap koperasi terutama dalam hal pemberian pinjaman kredit agribisnis. Diduga bahwa jika persepsi anggota terhadap program agribisnis akan berhubungan nyata dengan partisipasi anggota.

Berdasarkan Hasil Penelitian dapat diketahui nilai koefisien korelasi persepsi $\left(\mathrm{X}_{9}\right)$ dengan Partisipasi (Y). Hasil analisis uji t-hitung (2,09977) lebih besar dari nilai t-tabel $(2,01173)$ dengan taraf kepercayaan $95 \%(\alpha / 2=0,025)$. Diketahui bahwa persepsi mempunyai hubungan yang nyata positif dengan tingkat partisipasi Anggota.

Dengan adanya persepsi yang baik terhadap koperasi terutama dengan program kredit agribisnis tidak menjamin tingkat partisipasi anggota juga akan semakin tinggi terhadap koperasi. Karena partisipasi yang baik belum tentu diikuti dengan partisipasi yang baik pula.

\section{KESIMPULAN}

Berdasarkan hasil penelitian dan pembahasan yang telah dilakukan, maka dapat disimpulkan sebagai berikut :

Deskripsi faktor-faktor sosial ekonomi dan psikologi pada umumnya anggota berumur muda, pendidikan formal setingkat SMP, lamanya jadi anggota dengan kategori lama, jumlah tanggungan keluarga sedikit, penerimaan rumah tangga dengan kategori rendah, motivasi pengembalian kredit dengan kategori, persepsi terhadap pelayanan kategori baik, dan persepsi anggota terhadap program agribisnis dengan kategori baik. Pada umumnya tingkat Partisipasi anggota Koperasi Citra Baru Sektor Agribisnis dikategorikan pada kategori sedang atau cukup baik. Faktor-faktor yang berhubungan nyata positif adalah pendidikan formal, Lamanya jadi anggota, motivasi pengembalian kredit dan persepsi anggota terhadap pelayanan 


\section{DAFTAR PUSTAKA}

Anoraga Panji .2003. Dinamika Koperasi. Rineka Cipta, Jakarta. . 2002. Koperasi Kewirausahaan Dan Usaha Kecil. Rineka cipta, jakarta.

Badan Pusat Statistik. 2004. Kontribusi Sektor Pertanian dalam PDRB Propinsi Bengkulu. . BPS Bengkulu

Kartasaputra, Bambang S dkk.1994. Koperasi Indonesia Berdasarkan Pancasila dan UUD 1945. Rhineka Cipta. Jakarta.

Murtiningrum. 2003. Partisipasi Masyarakat Bantuan Bantuan Proyek BRDP Pada Usaha Konsumtif Pedesaan. Skripsi Mahasiswa Sosial Ekonomi Pertanian UNIB. Bengkulu (tidak dipublikasikan).

Nazir.M. 1988. Metode Penelitian. Ghalia Indonesia. Jakarta.

Siagian, S.P. Teknik Menumbuhkan dan Memelihara Prilaku Organisasional. Gunung Agung, Jakarta.

Siegel,Sidney.1992. Statistik Non Parametrik untuk Ilmu-Ilmu Sosial, terjemahan Zanzawi, Suyuti dan Landung Simatupang, Gramedia, Jakarta.

Singarimbun, M dan Effendi. 1989. Metode Penelitian Survai. LP3ES. Jakarta.

Sinungan Muchdarsya. 1984. Managemen Kredit. Bina Aksara, Jakarta.

Siwijatmo Djarot.1992. Koperasi di Indonesia. Fakultas Ekonomi. Universitas Indonesia, Jakarta

Subyakto Harsoyono , Bambang Tricahyono. 1995. Ekonomi Koperasi. Liberty, Yogyakarta. Sugiono. 2003. Statistik Non Parametrik Untuk Penelitian. Alfabeta. Bandung

Suwandi dan Ima. 1980. Koperasi Ekonomi Yang Berwatak Sosial. Barata Karya Aksara. Jakarta. 